\title{
Nature of gene action for yield and yield components in exotic genotypes of Italian millet [Setaria italica (L.) Beauv]
}

\author{
P. Lakshmi Prasanna*, J. S. V. Samba Murthy, P. V. Rama Kumar and V. Srinivasa Rao \\ Department of Genetics and Plant Breeding, Agricultural College, Bapatla 522101, Andhra Pradesh, India.
}

Accepted 20 March, 2013

\begin{abstract}
The present investigation was carried out with the objective to find out the extent of genetic variation, heritability and genetic advance for 13 characters in 34 exotic genotypes of Italian millet during Autumn 2008 and Spring 2009. High phenotypic coefficients of variation (PCV) coupled with high genotypic coefficients of variation (GCV) were observed for grain yield per plant, ear weight, calcium content and carotene during both seasons. The trait $\mathbf{1 0 0 0}$ grain weight recorded high PCV and GCV during Autumn, whereas number of productive tillers per plant and straw weight during Spring. Straw weight showed high GCV during Autumn. It indicated presence of wider variability for these traits in the genotypes studied. High heritability coupled with high genetic advance as percent of mean recorded for all characters except days to $50 \%$ flowering, days to maturity and plant height during both seasons reveals operation of additive gene action in the inheritance of these traits and improvement in these characters is possible through simple selection.
\end{abstract}

Key words: Italian millet, gene action, Seteria, foxtail millet.

\section{INTRODUCTION}

Among the six small millets, Italian millet [Setaria italica (L.) Beauv] is the most important crop next to finger millet [Eleusine coracana (L.) Gaertn]. Italian millet is also known as foxtail millet, German millet, Chinese millet, and Hungarian millet. It is commonly known as korra in Andhra Pradesh. It is one of the world's oldest cultivated crops. Its domestication and cultivation is estimated to have occurred over 4000 years ago (Chang, 1968). It was the most important food crop of the Neolithic culture in China. It is generally raised as rainfed crop in India. It is cultivated in Andhra Pradesh, Karnataka, Maharashtra and Hilly areas of Northern India. Italian millet is grown for human food in North Africa, Southeastern Europe, Japan and India. It is usually cooked as a whole or made into meal or into beer. It can also make useful hay or silage. In addition, foxtail millet is consumed as stiff porridge called sargati, or as leavened bread known as roti, after the dehulled grain has been milled into flour. Foxtail millet with a short growing period is grown extensively in diverse agro-climatic regions for grain and fodder. It is known for its drought tolerance and is an indispensable crop of vast rain fed areas in semi-arid regions in India. It is also grown in nutrient deficient soils and possesses tolerance to pests and diseases. The grain is a good source of protein and contains $\beta$ carotene. In any crop improvement programme, the knowledge on the nature of gene action and inheritance of characters is essential so as to adopt a suitable breeding methodology in crop improvement. Presence of a wider spectrum of variability will enhance the chances 
Table 1. Mean, variability, heritability, genetic advance as percent of mean in Italian millet [Setaria italica (L.) Beauv] during Autumn 2008 and Spring 2009 for exotic genotypes

\begin{tabular}{|c|c|c|c|c|c|c|c|c|c|c|c|c|c|}
\hline \multirow{2}{*}{ S/N } & \multirow{2}{*}{ Character } & \multicolumn{2}{|c|}{ Mean } & \multicolumn{2}{|c|}{ Range } & \multicolumn{2}{|c|}{ GCV\% } & \multicolumn{2}{|c|}{ PCV\% } & \multicolumn{2}{|c|}{$h^{2} b$} & \multicolumn{2}{|c|}{ GA(as \% mean) } \\
\hline & & Autumn & Spring & Autumn & Spring & Autumn & Spring & Autumn & Spring & Autumn & Spring & Autumn & Spring \\
\hline 1 & Days to $50 \%$ flowering & 54.42 & 49.55 & $50.75-57.75$ & $46.00-52.75$ & 3.33 & 3.48 & 3.66 & 3.78 & 83.06 & 84.72 & 6.26 & 6.61 \\
\hline 2 & Plant height(cm) & 62.91 & 109.57 & $54.11-74.36$ & $101.42-124.94$ & 8.20 & 5.42 & 8.37 & 5.54 & 96.16 & 95.59 & 16.58 & 10.92 \\
\hline 3 & Days to maturity & 90.03 & 81.88 & $84.75-98.00$ & $79.00-85.00$ & 4.03 & 2.17 & 4.19 & 2.34 & 92.67 & 86.09 & 8.00 & 4.14 \\
\hline 4 & Number of productive tillers/ plant & 2.92 & 11.66 & $2.10-4.13$ & $6.10-18.20$ & 18.36 & 24.99 & 18.90 & 25.11 & 94.37 & 99.00 & 36.76 & 51.22 \\
\hline 5 & Flag leaf area $\left(\mathrm{cm}^{2}\right)$ & 27.62 & 70.70 & $20.65-42.70$ & $51.81-106.76$ & 17.73 & 19.52 & 17.98 & 19.69 & 97.21 & 98.27 & 36.02 & 39.87 \\
\hline 6 & Ear length(cm) & 8.90 & 18.37 & $5.75-12.70$ & $14.64-21.89$ & 19.77 & 9.48 & 19.99 & 9.57 & 97.77 & 98.17 & 40.26 & 19.36 \\
\hline 7 & Ear weight (g) & 2.26 & 4.95 & $1.51-3.26$ & $2.33-7.82$ & 20.89 & 29.75 & 21.40 & 29.89 & 95.30 & 99.10 & 42.02 & 61.02 \\
\hline 8 & Straw weight (g) & 18.77 & 44.89 & $12.30-34.47$ & $24.76-64.73$ & 41.14 & 22.21 & 41.48 & 22.29 & 98.38 & 99.28 & 84.07 & 45.59 \\
\hline 9 & 1000 grain weight $(\mathrm{g})$ & 1.63 & 2.61 & $1.07-2.33$ & $2.13-3.90$ & 24.28 & 15.09 & 24.80 & 15.47 & 95.88 & 95.13 & 48.98 & 30.33 \\
\hline 10 & Carotene $(\mathrm{mg} / 100 \mathrm{cg})$ & 0.20 & 0.23 & $0.13-0.45$ & $0.13-0.55$ & 35.59 & 39.87 & 36.99 & 41.54 & 92.59 & 92.12 & 70.55 & 78.83 \\
\hline 11 & Crude protein \% & 7.04 & 8.99 & $4.55-8.98$ & $6.47-11.84$ & 15.23 & 12.94 & 15.27 & 12.98 & 99.47 & 99.36 & 31.30 & 26.57 \\
\hline 12 & Calcium content (mg/100 g) & 3.20 & 4.20 & $1.60-7.72$ & $2.20-8.44$ & 40.26 & 36.81 & 40.36 & 36.91 & 99.53 & 99.46 & 82.75 & 75.63 \\
\hline 13 & Grain yield/ plant (g) & 6.25 & 29.32 & $2.22-12.35$ & $7.91-52.49$ & 47.57 & 42.16 & 48.61 & 42.94 & 95.80 & 96.41 & 95.93 & 85.28 \\
\hline
\end{tabular}

PCV, Phenotypic coefficient of variation; GCV = genotypic coefficient of variation; $\mathbf{h}^{2} \mathbf{b}$, Heritability (Broad sense).

of selecting a desired genotype. Besides genetic variability, knowledge on heritability and genetic advance measures the relative degree to which a character is transmitted to progeny, thereby helps the breeder to employ a suitable breeding strategy to achieve the objective. Keeping the above points in view, the present investigation was carried out with the objective to find out the extent of genetic variation, heritability and genetic advance.

\section{MATERIALS AND METHODS}

The present investigation was undertaken at Agricultural College Farm, Bapatla, Guntur (Dt.), Andhra Pradesh with the 34 exotic genotypes of Italian millet [S. italica (L.) Beauv] collected from All India Co-ordinated Small Millets Improvement Project (AICSMIP), Bengaluru. Studies were carried out separately during two seasons of 2008 to 2009 , namely Autum 2008 and Spring 2009. The genotypes are sown separately in randomized block design with four replications. Each genotype was sown in four rows of $5 \mathrm{~m}$ in length spaced at $25 \times 10 \mathrm{~cm}$ in apart. Data were collected on 10 randomly tagged competitive plants per genotype per replication for number of productive tillers per plant, plant height, flag leaf area, ear length, ear weight, straw weight and grain yield. However, data on days to $50 \%$ flowering, days to maturity, grain protein $\%$, calcium content and grain $\beta$-carotene were recorded on plot basis. Phenotypic and genotypic coefficients of variations (PCV and GCV) were computed according to Burton (1952). As suggested by Sivasubramanian and Menon (1973), GCV and PCV were categorized. Heritability in broad sense was estimated as per Lush (1940). The range of genetic advance as percent of mean was classified as suggested by Johnson et al. (1955). The estimates of mean, range, PCV, GCV, heritability $\left(\mathrm{h}^{2} \mathrm{~b}\right)$ and genetic advance as percent of mean (GAM) for Indian genotypes are presented in Table 1.

\section{RESULTS AND DISCUSSION}

In general for all the characters involved in this study, the PCV is greater than GCV. This indicates little influence of environment on the expression of character. In the present study, most of the characters showed high heritability and genetic advance in both seasons. High heritability accompanied with high genetic advance reveals that most likely the heritability is due to additive gene effects and simple selection may be rewarding for improving a particular trait. It can be exploited by pure line selection and mass selection. High heritability coupled with low or moderate genetic advance can be exploited through heterosis breeding.

Burton (1952) and Swarup and Chaugle (1962) indicated that genetic variability together with the heritability would give a better idea on the amount of genetic advance expected out of selection. The magnitude of heritable variability is the most important aspect of genetic contribution of the breeding material, which has close relationship on its response to selection (Panse, 1957). 


\section{Days to $50 \%$ flowering}

The variability for this trait ranged from 50.75 to 57.75 days with a mean of 54.42 days recorded during Autumn, while the range was from 46 to 52.75 days with a mean of 49.55 days during Spring. Low GCV (A: 3.33 and S: 3.48) and PCV (A: 3.66 and S: 3.78$)$ and high heritability (A: 83.06 and $S: 84.72$ ) coupled with low genetic advance (A: 6.26 and S: 6.61) were observed during both the seasons.

High heritability accompanied with low genetic advance during both seasons indicates the role of non-additive gene action in the inheritance of this trait. The high heritability being exhibited may be due to influence of environment rather than genotype and selection for such trait may not be rewarding. Through heterosis breeding high heritability can be exploited. Similar results were earlier reported by Patil and MohanKumar (1989), Selvarani and Gomathinayagam (2000), and Lakshmana and Guggari (2001).

\section{Plant height (cm)}

Among exotic genotypes, the variability showed by this trait ranged from 54.11 to 74.36 with a mean of 62.91 during Autumn, while the range was from 101.42 to 124.94 with a mean of 109.57 during Spring. Low GCV (A: 8.20 and S: 5.42 ) and PCV (A: 8.37 and S: 5.54$)$ and high heritability (A: 96.16 and $S:$ 95.59) linked to moderate genetic advance (A: 16.58 and $S: 10.92)$ were recorded during both autumn and spring.

High heritability coupled with moderate genetic advance found which reveals the role of non-additive gene action in governing this trait. High heritability is due to favorable influence of environment rather than genotype alone hence direct selection for this trait may not be rewarding. The results are in agreement with Lakshmana and Guggari (2001).

\section{Days to maturity}

The variability for this trait ranged from 84.75 to 98.00 days with a mean of 90.03 days during Autumn, while the range was from 79.00 to 85.00 days with a mean of 81.88 days during Spring. Low GCV (A: 4.03 and S: 2.17$)$ and PCV (A: 4.19 and S: 2.34) and high heritability (A: 92.67 and $S: 86.09)$ joined with low genetic advance (A: 8.00 and S: 4.14) were observed during both Autumn and Spring.

High heritability together with low genetic advance noted revealed the importance of non-additive gene action in governing this trait. High heritability may be due to favorable influence of environment rather than genotype, hence, simple selection for this trait may not be rewarding. Similar findings were earlier reported by
Selvarani and Gomathinayagam (2000), and Lakshmana and Guggari (2001).

\section{Number of productive tillers per plant}

This trait exhibited a range of variation in exotic genotypes from 2.10 to 4.13 with a mean of 2.92 during Autumn, while the range was from 6.10 to 18.20 with a mean of 11.66 during Spring. Moderate GCV (18.36) and PCV (18.90) were observed during Autumn, whereas high genotypic (24.99) and PCV (25.11) were noted during Spring. High heritability (A: 94.37 and S: 99.0) joined with high genetic advance (A: 36.76 and $S: 51.22)$ were recorded during both Autumn and Apring seasons.

Wide variability was also observed by Nagarajan and Prasad (1980), Islam et al. (1989), Chidambaram and Palanisamy (1995), Balagopal (1997), and Selvarani and Gomathinayagam (2000). High heritability in conjunction with high genetic advance was found both reveal that, the heritability is due to additive gene effects and simple selection may be effective for improving this trait. It can be exploited by pure line selection and mass selection. These results are in agreement with Athwal and Gian Singh (1966), Sandhu et al. (1974), Gurunadha and Appa (1984) and Selvarani and Gomathinayagam (2000).

\section{Flag leaf area $\left(\mathrm{cm}^{2}\right)$}

Variability observed for this trait ranged from 20.65 to 42.70 with a mean of 27.62 in exotic genotypes during Autumn, while the range was from 51.81 to 106.76 with a mean of 70.70 during Spring. Moderate GCV (A: 17.73 and S: 19.52) and PCV (A: 17.98 and S: 19.69) and high heritability (A: 97.21 and $S$ : 98.27) paired with high genetic advance (A: 36.02 and S: 39.87) were recorded during both Autumn and Spring.

High heritability and high genetic advance was found which indicate that, the heritability is due to additive gene effects and simple selection may be rewarding for improving this trait. It can be exploited by pure line selection and mass selection. Similar results were earlier reported by Sirisha (2008).

\section{Ear length $(\mathrm{cm})$}

Ear length exhibited a range of variation in exotic genotypes from 5.75 to 12.70 with a mean of 8.90 during Autumn, while the range was from 14.64 to 21.89 with a mean of 18.37 during Spring. Moderate GCV (19.77) and PCV (19.99) were observed during Autumn, while low genotypic (9.48) and PCV (9.57) during Spring. High heritability (97.77) and high genetic advance (40.26) were observed during Autumn, while high heritability (98.17) coupled with moderate genetic advance as percent of 
mean (19.36) were observed during Spring.

Patil and MohanKumar (1989), Chidambaram and Palanisamy (1995), Lakshmana and Guggari (2001) and Nirmalakumari et al. (2008) also reported similar findings in case of variability. Similar observations on heritability and genetic advance were earlier reported by Athwal and Gian Singh (1966), Sandhu et al. (1974), Gurunadha and Appa (1984), Patil and MohanKumar (1989), Chidambaram and Palanisamy (1995), Lakshmana and Guggari (2001), and Nirmalakumari et al. (2008).

\section{Ear weight (g)}

Variability observed for this trait ranged from 1.51 to 3.26 with a mean of 2.26 in exotic genotypes during Autumn, while the range was from 2.33 to 7.82 with a mean of 4.95 during Spring. High GCV (A: 20.89 and S: 29.75) and PCV (A: 21.40 and S: 29.89) were recorded during both seasons. High heritability (A: 95.30 and $S: 99.10)$ coupled with high genetic advance (A: 42.02 and S: 61.02) were observed during Autumn and Spring seasons. Contrary to this, Patil and MohanKumar (1989) reported moderate heritability and high genetic advance, while Chidambaram and Palanisamy (1995) observed low heritability and genetic advance for this trait. This might be due to differences in breeding material and environments studied.

\section{Straw weight (g)}

A range of 12.30 to 34.47 with a mean of 18.77 was recorded by this trait in exotic genotypes during Autumn, while the range was from 24.76 to 64.73 with a mean of 44.89 during Spring. High GCV (A: 41.14 and S: 22.21) and PCV (A: 41.48 and S: 22.29) and high heritability (A: 98.38 and S: 99.28) coupled with high genetic advance (A: 84.07and S: 45.59) were noted during both Autumn and Spring. Wide variability was also observed by Patil and MohanKumar (1989) and Chidambaram and Palanisamy (1995).

\section{0 grain weight $(g)$}

Among exotic genotypes, the variability showed by 1000 grain weight ranged from 1.07 to 2.33 with a mean of 1.63 during Autumn, while the range was from 2.13 to 3.90 with a mean of 2.61 during Spring. High GCV (24.28) and PCV (24.80) were observed during Autumn, whereas moderate genotypic (15.09) and PCV (15.47) were noted during Spring. High heritability (A: 95.88 and S: 95.13) linked to high genetic advance (A: 48.98 and S: 30.33) were recorded during both Autumn and Spring seasons. Heritability and genetic advance results are in agreement with Sandhu et al. (1974), Gurunadha and
Appa (1984), Patil and MohanKumar (1989), and Nirmalakumari et al. (2008).

\section{Grain $\beta$-carotene content $(\mathrm{mg} / \mathbf{1 0 0} \mathrm{g})$}

In exotic genotypes, the variability for this trait ranged from 0.13 to 0.45 with a mean of 0.20 during Autumn, while the range was from 0.13 to 0.55 with a mean of 0.23 during Spring. High GCV (A: 35.59 and S: 39.87) and PCV (A: 36.99 and S: 41.54$)$ and high heritability (A: 92.59 and $S: 92.12$ ) together with high genetic advance (A: 70.55 and S: 78.83) were observed during Autumn and Spring. Similar results were earlier reported by Sirisha (2008).

\section{Crude protein percent}

This trait exhibited a range of variation in exotic genotypes from 4.55 to 8.98 with a mean of 7.04 during Autumn, while the range was from 6.47 to 11.84 with a mean of 8.99 during Spring. Moderate GCV (A: 14.23 and S: 12.94) and PCV (A: 14.27 and S: 12.98) and high heritability (A: 99.47 and S: 99.36) coupled with high genetic advance (A: 31.30 and S: 26.57) were recorded during both seasons. Similar results were earlier reported by Sirisha (2008).

\section{Calcium content $(\mathrm{mg} / 100 \mathrm{~g})$}

Variability observed for this trait ranged from 1.60 to 7.72 with a mean of 3.20 in exotic genotypes during Autumn, while the range was from 2.20 to 8.44 with a mean of 4.20 during Spring. High GCV (A: 40.26 and S: 36.81 ) and PCV (A: 40.36 and S: 36.91$)$ and high heritability (A: 99.53 and S: 99.46$)$ joined with high genetic advance (A: 82.75 and S: 75.63 ) were recorded during both seasons. These results are in accordance with Sirisha (2008).

\section{Grain yield per plant (g)}

A range of 2.22 to 12.35 with a mean of 6.25 was recorded by this trait in exotic genotypes during Autumn, while the range was from 7.91 to 52.49 with a mean of 29.32 during spring. High GCV (A: 47.57 and S: 42.16) and PCV (A: 48.61 and S: 42.94) and high heritability (A: 95.80 and $S: 96.41)$ coupled with high genetic advance (A: 95.93 and S: 84.28) were observed during both seasons. Similar findings were earlier reported by Islam et al. (1989), Selvarani and Gomathinayagam (2000), and Muhammed and Hussain (2004) for variability and in case of heritability and genetic advance by Athwal and Gian (1966), Sandhu et al. (1974), Gurunadha and Appa (1984), Selvarani and Gomathinayagam (2000), and 
Lakshmana and Guggari (2001).

\section{ABBREVIATIONS}

PCV, Phenotypic coefficients of variation; GCV, genotypic coefficients of variation; A, autumn; S, spring.

\section{REFERENCES}

Athwal DS, Gian S (1966). Variability in kangni-1. Indian J. Genet. Plant Breed. 26(2):142-152.

Balagopal G (1997). Studies on variability, correlation, path analysis and $D^{2}$ analysis for yield and yield components in foxtail millet [Setaria italica (L.) Beauv]. M. Sc. (Ag.) Thesis, Tamil Nadu Agricultural University, Coimbatore.

Burton GW (1952). Quantitative inheritance in grasses. Proc. $6^{\text {th }}$ Int. Congr. pp. 277-283.

Chang K (1968). Archeology of ancient China. Sci. 162:519-526.

Chidambaram S, Palanisamy S (1995). Variability and correlation studies of dry matter with reference to selection criteria in foxtail millet (Setaria italica). Madras Agric. J. 82(1):1-3.

Gurunadha RY, Appa RP (1984). Genetic variability in yield and certain yield components of Italian millet. Madras Agric. J. 71:332-33.

Islam M, Mannujan H, Sarkar S (1989). An evaluation of foxtail millet germplasam in Bangladesh. Bangladesh J. Plant Breed. Genet. 2:5961.

Johnson HW, Robinson HF, Comstock R E (1955). Estimates of genetic and environmental variability in soybean. Agron. J. 47:314-318.

Lakshmana D, Guggari AK (2001). Genetic variability studies in foxtail millet [Setaria italica (L.) Beauv]. Karnataka J. Agric. Sci. 14(2):311314.
Lush JL (1940). Intra-sire correlation on regression of offSpring on dams as a method of estimating heritability of characters. Proc. Am. Soc. Anim. Prod. 33:392-301.

Muhammed B, Hussain SK (2004). Genetic variability and correlation studies in foxtail millet [Setaria italica (L.) Beauv]. Crop Res. 28(13):94-97.

Nagarajan K, Prasad MN (1980). Studies on genetic diversity in foxtail millet [Setaria italica (L.) Beauv]. Madras Agric. J. 67(1):28-38.

Nirmalakumari A, Ganapathy S, Murugan R (2008). Studies on variability and descriptive statistics in foxtail millet [Setaria italica (L.) Beauv] germplasm. Crop Res. 35(1-2):80-82.

Panse VG (1957). Genetics of quantitative characters in relation to plant breeding. Ind. J. Gene. Plant Breed. 17:318-328.

Patil MS, MohanKumar HD (1989). Studies on Genetic variability for yield and its components in foxtail millet [Setaria italica (L.) Beauv]. Karnataka J. Agric. Sci. 2(3):165-169.

Sandhu TS, Arora BS, Yashvir S (1974). Interrelationships between yield and yield components in foxtail millet. Indian J. Agric. Sci. 44(9):563-566.

Selvarani M, Gomathinayagam P (2000). Genetic variability in foxtail millet [Setaria italica (L.) Beauv]. Crop Res. 20(3):553-554.

Sirisha ABM (2008).Character association and genetic divergence in Italian millet (Setaria italica (L.) Beauv). M.Sc. (Ag.) Thesis, Acharya N.G. Ranga Agricultural University, Hyderabad.

Sivasubramanian S, Menon M (1973). Heterosis and inbreeding depression in rice. Madras Agric. J. 60:1139-1149.

Swarup S, Chaugle BS (1962). Studies on genetic variability in sorghum; phenotypic variation and heritable component in some quantitative characters contributing towards yield. Indian J. Genet. Plant Breed. 22:31-36. 